\title{
Spatial aftershock distribution of the 26 December 2004 great Sumatra-Andaman earthquake in the northern Sumatra area
}

\section{Jing-Yi Lin}

CEREGE, UMR6635, Chaire de Géodynamique, Collège de France, CNRS, Europôle de l'Arbois, B.P. 80, F-13545 Aix en Provence, France

Now at Institute of Geophysics, National Central University, 300 Jhongda Road, Jhongli, Taoyuan County 32001, Taiwan (jylin@ncu.edu.tw)

\section{Xavier Le Pichon and Claude Rangin}

CEREGE, UMR6635, Chaire de Géodynamique, Collège de France, CNRS, Europôle de l'Arbois, B.P. 80, F-13545 Aix en Provence, France (lepichon@cdf-u.3mrs.fr; rangin@cdf-u.3mrs.fr)

\section{Jean-Claude Sibuet}

Centre de Brest, Ifremer, B.P. 70, F-29280 Plouzane, France (jcsibuet@ifremer.fr)

\section{Tanguy Maury}

CEREGE, UMR6635, Chaire de Géodynamique, Collège de France, CNRS, Europôle de l'Arbois, B.P. 80, F-13545 Aix en Provence, France (tanguy.maury@ifremer.fr)

[1] In July 2005, about 6 months after the 2004 great Sumatra-Andaman earthquake, 20 ocean bottom seismometers were deployed in the northern Sumatra area. More than 1000 events were identified during the 12 day recording period. After relocation, the seismicity shows different patterns on each side of the Lower Splay Fault. East of this feature and beneath the Aceh basin and fore arc, the deep earthquakes outline the subduction megathrust fault. West of it, the aftershocks distribution is strongly influenced by the active $\mathrm{N}-\mathrm{S}$ oceanic fracture zones of the subducted plate. Two $\mathrm{N}-\mathrm{S}$ trending clusters of $10-$ to $50-\mathrm{km}-$ deep earthquakes observed below the lower wedge are interpreted as reactivated oceanic fracture zones. The postseismic activity suggests a significant influence of the $\mathrm{N}-\mathrm{S}$ active fracture zones of the oceanic plate on the toe of the wedge explaining the dextral wrenching of wedge thrusts in the morphology. The megathrust fault does not extend to the trench but outcrops east of these active oceanic fractures and seems to merge upward along the Lower Splay Fault where shallow earthquakes are observed.

Components: 8340 words, 9 figures.

Keywords: 2004 great Sumatra-Andaman earthquake; Sumatra trench; Andaman trench; aftershocks; splay faults; oblique subduction.

Index Terms: 3060 Marine Geology and Geophysics: Subduction zone processes (1031, 3613, 8170, 8413); 7230 Seismology: Seismicity and tectonics (1207, 1217, 1240, 1242); 8010 Structural Geology: Fractures and faults.

Received 23 February 2009; Accepted 20 March 2009; Published 27 May 2009.

Lin, J.-Y., X. Le Pichon, C. Rangin, J.-C. Sibuet, and T. Maury (2009), Spatial aftershock distribution of the 26 December 2004 great Sumatra-Andaman earthquake in the northern Sumatra area, Geochem. Geophys. Geosyst., 10, Q05006, doi:10.1029/2009GC002454. 


\section{Introduction}

[2] The Sumatra margin is seismically active [Newcomb and McCann, 1987; Zen, 1993]. Large subduction zone earthquakes have repeatedly occurred along the Sumatra and Andaman subduction zones where the Indo-Australia plate is subducting beneath the Burma plate (Figures 1 and 2). Earthquakes are mainly located in the fore-arc domain but some of them occur along the Sumatra fault (Figure 2). The 26 December 2004 SumatraAndaman $\mathrm{Mw}=9.3$ earthquake was the second largest earthquake recorded during the last century. The rupture propagated about $1300 \mathrm{~km}$ northward [Ishii et al., 2005] and the maximum coseismic slip was close to $20 \mathrm{~m}$ offshore NW Sumatra [Ammon et al., 2005; Subarya et al., 2006]. Prior to the 2004 great Sumatra-Andaman earthquake, the seismicity was restricted to the area northeast of the Upper Splay fault (USF) along the plate interface at depths greater than $35 \mathrm{~km}$, and few teleseismic earthquakes were recorded below the accretionary wedge [Lay et al., 2005; Engdahl et al., 2007] (Figure 2a). In contrast, the whole region became seismically active after the 2004 great SumatraAndaman earthquake (Figure 2b). The downdip limit of the rupture zone determined from teleseismic earthquakes is situated at a depth of $\sim 50 \mathrm{~km}$ and a distance of $\sim 240 \mathrm{~km}$ landward from the trench axis [Dewey et al., 2007; Engdahl et al., 2007]. Most of the teleseismic aftershocks of magnitude larger than $\mathrm{Mw}=5.5$ are confined to the plate interface. The objectives of our study are to map the major postseismic active tectonic features of the upper and lower plates by using relocated earthquakes recorded during a dense passive ocean bottom seismometer (OBS) experiment carried out in this area [Sibuet et al., 2007] about 6 months after the 2004 great Sumatra-Andaman earthquake and to determine not only the relationship between the upper plate aftershocks and the detailed surface morphology established from multibeam and echo sounder data but also the relationships between lower and upper plate features.

\section{Geological Setting}

[3] In the Sumatra region, the Indian and Australian oceanic plates are subducting beneath the Sunda plate, over more than $5,500 \mathrm{~km}$, from northern Australia to Myanmar [Paul et al., 2001; Briggs et al., 2006; Gahalaut and Gahalaut, 2007]. Southeast of Sumatra, the convergence is nearly orthogonal to the plate boundary and becomes oblique off northern Sumatra [Michel et al., 2001; Bock et al., 2003] (Figure 1), where the motion is partitioned between a normal-to-thetrench motion [e.g., Fitch, 1972; Newcomb and McCann, 1987; McCaffrey, 2002] and a rightlateral strike-slip motion along the Sumatra Fault [Sieh and Natawidjaja, 2000] (see also Delescluse and Chamot-Rooke [2007] for a recent determination of the plate kinematics). In northern Sumatra, geodetic measurements show that the right-lateral motion along the Sumatra Fault does not represent the whole trench-parallel motion as about $15 \%$ of it is absorbed within the wedge (X. Le Pichon, Le séisme de Sumatra du 26 décembre 2004 et la subduction Indo-Australienne, Cours du Collège de France, Chaire de Géodynamique, Cours et Séminaires, 2005-2006, http://www.cdf.u-3 mrs.fr/ 〜lepichon/).

[4] In the oceanic plate, the large-scale features observed in the Wharton Basin are the Ninety East Ridge and the Investigator Fracture Zone (FZ) $\left(98^{\circ} \mathrm{E}\right)$. In between, a set of roughly $\mathrm{N}-\mathrm{S}$ subparallel fracture zones has been identified from bathymetric, gravity and magnetic data [Deplus et al., 1998; Barckhausen, 2006; Delescluse and Chamot-Rooke, 2007; Sibuet et al., 2007]. These N-S fracture zones are currently reactivated as left-lateral strike-slip faults [Deplus et al., 1998; Delescluse and ChamotRooke, 2007; Engdahl et al., 2007]. During the interseismic and postseismic periods, a few moderate size earthquakes with $\mathrm{N}-\mathrm{S}$ left-lateral and rightlateral strike-slip mechanisms occurred in the lower plate and in the wedge, respectively [Abercrombie et al., 2003; Dewey et al., 2007; Engdahl et al., 2007] (Figures 2c and 2d). These types of earthquakes, consistent with shear faulting on nearly $\mathrm{N}-\mathrm{S}$ planes were also recorded by a local network, along the northern prolongation of the Investigator FZ, down to a depth of $150 \mathrm{~km}$ [Fauzi et al., 1996], suggesting that the oceanic lower plate stress relaxation is affecting the upper plate. Thus, the subduction of active oceanic fracture zones ridges might have an effect on the deformation of the upper plate as confirmed by the indentation of the Sumatra-Andaman trench, southwest of Simeulue Island [Zen, 1993].

[5] Part of the aftershock activity is located trenchward at depths less than $35 \mathrm{~km}$, filling areas where previous seismicity was absent [Engdahl et al., 2007] (Figure 2b). Many aftershocks are also observed at depths between 35 and $60 \mathrm{~km}$, especially in the northern Sumatra area where an intense, 150-km-long NW-SE cluster of aftershock activity was observed and characterized by 


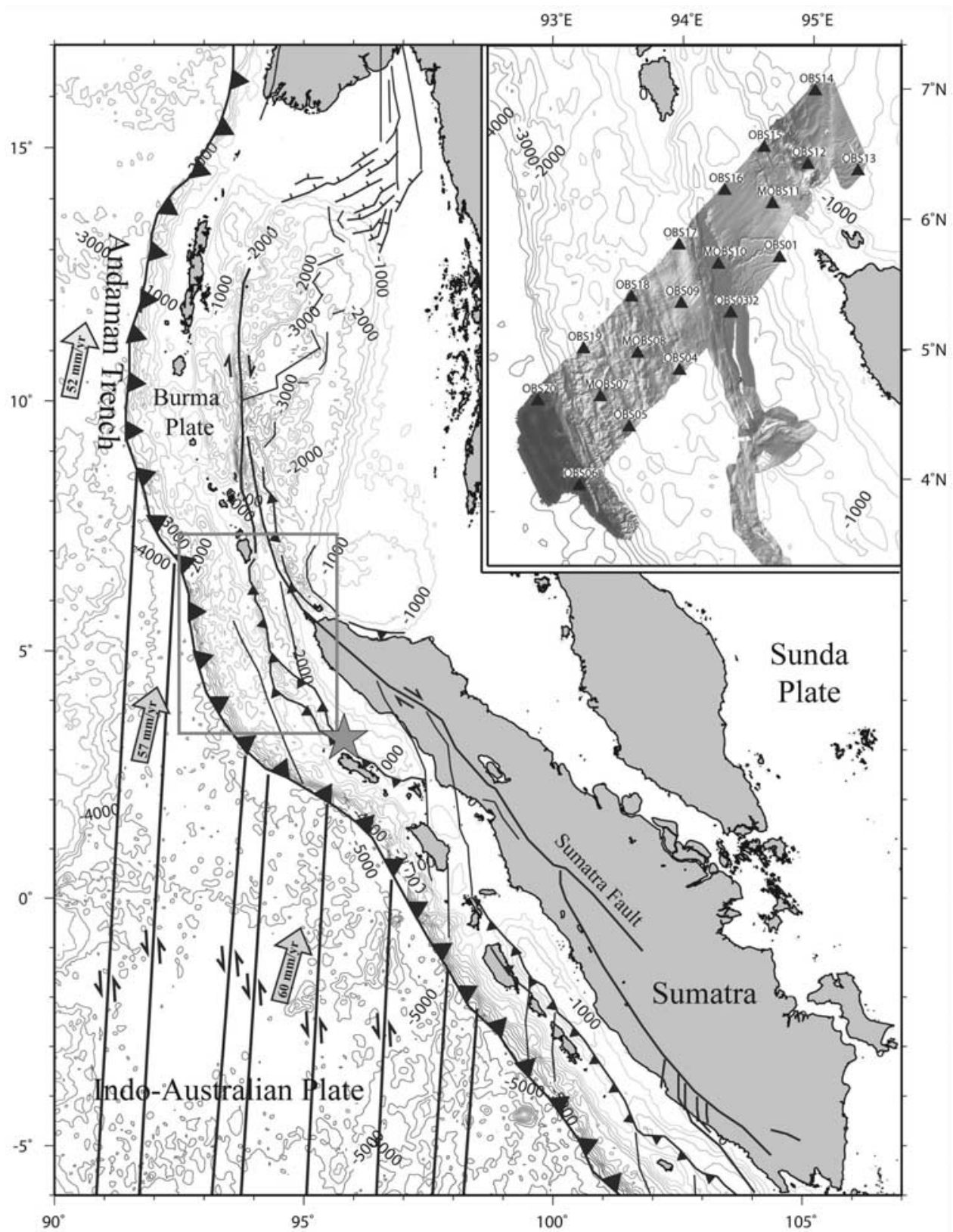

Figure 1. Tectonic framework of the Sumatra-Andaman subduction system. Grey arrows indicate the NUVEL-1A relative motion between the Indo-Australian and Sunda plate [DeMets et al., 1994]. The gray star shows the epicenter of the 26 December 2004 great Sumatra-Andaman earthquake. The black lines with triangles are the main tectonic features [Pubellier et al., 2005]. The Sumatra Fault is taken from Sieh and Natawidjaja [2000]. In the inset, detailed bathymetry of the survey area of the Sumatra Aftershocks cruise [Sibuet et al., 2007] located in the gray square box in the general map. Black triangles show the positions of the 20 OBSs.

focal mechanism solutions suggesting their occurrence along the plate interface [Araki et al., 2006; Dewey et al., 2007; Engdahl et al., 2007]. Araki et al. [2006] and Sibuet et al. [2007] have also shown that the aftershocks recorded by the Japanese and French OBS networks in January and July-August 2005 respectively, suggest the presence of seismically active splay faults that originate at the plate interface décollement level and propagate to the seafloor.

\section{Data Acquisition}

[6] During the Sumatra Aftershocks cruise (R/V Marion Dufresne, 15 July to 9 August 2005), 20 short-term OBSs were deployed offshore the north- 

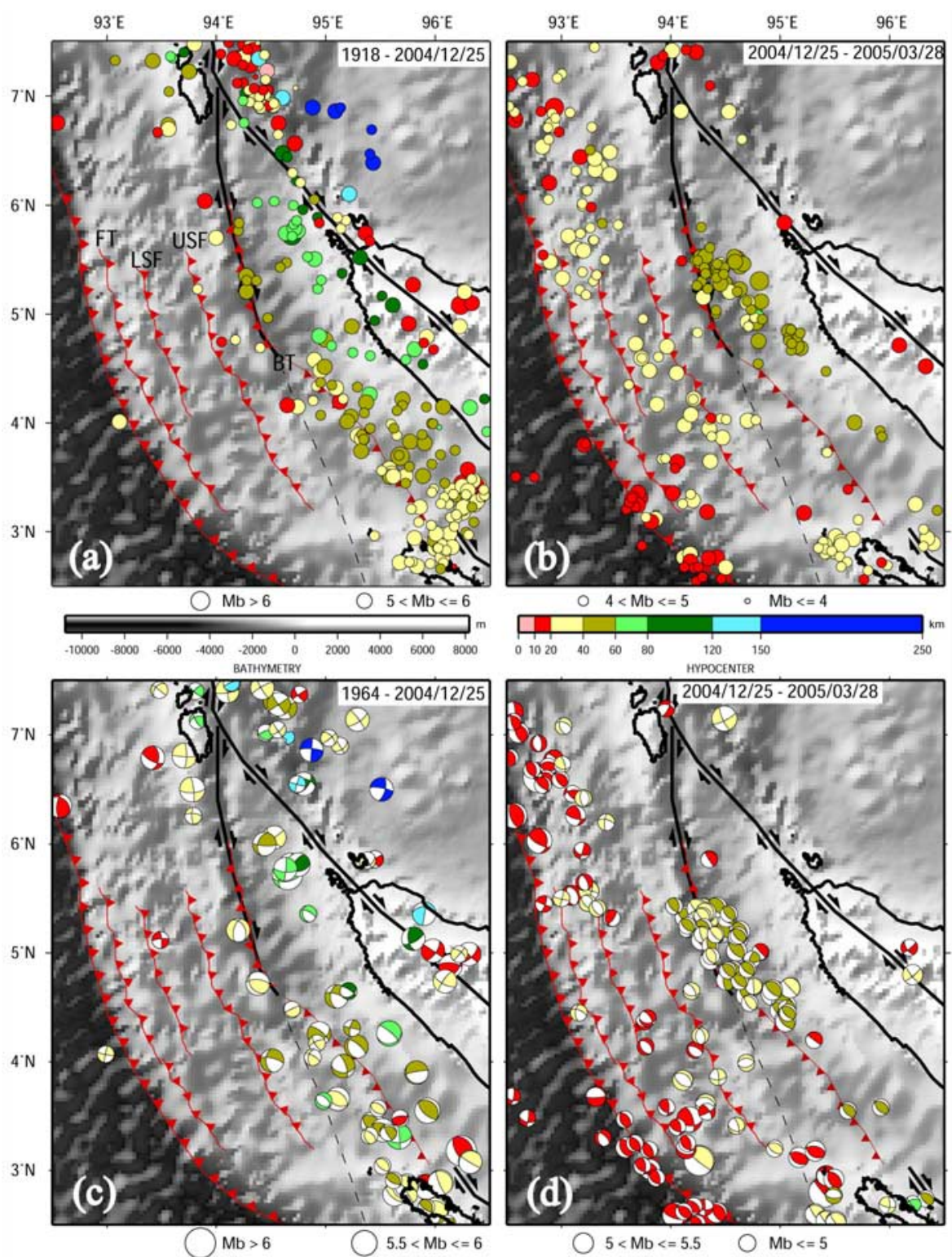

Figure 2. (a) Seismicity in the Sumatra-Andaman region relocated [Engdahl et al., 2007] and color classified by depth from 1918 through 25 December 2004. The size of hypocenters is function of the magnitude Mb. (b) Aftershock seismicity [Engdahl et al., 2007] between the dates of the Sumatra and Nias events. (c) Focal mechanisms from the Harvard catalog. Color classified by depth from 1964 through 25 December 2004. Beach balls are in lower hemisphere projection. (d) Aftershocks focal mechanisms from the Harvard catalog color classified by depth from 25 December 2004 through 28 March 2005. Bathymetry and topography in gray [Sandwell and Smith, 1994]. The red lines with triangles are the main tectonic features (Rangin et al., submitted manuscript, 2008). FT, Frontal Thrust; LSF, Lower Splay Fault; USF, Upper Splay Fault; BT, Backstop Thrust.

ern tip of Sumatra in a $370 \times 75 \mathrm{~km}$ area from the Wharton Basin to north of the Sumatra Fault system (inset in Figure 1). Seismic events were detected manually on continuous hydrophone and three-component records. Only events recorded on more than 3 OBSs were kept and an preliminary location was obtained by using the 1-D preliminary velocity law determined by Araki et al. [2006]. We used the HYPOCENTER method [Lahr, 1980; Lienert et al., 1988] which is based on the minimization of root mean square (rms) travel time residuals of $\mathrm{P}$ and $\mathrm{S}$ waves. The magnitude $\mathrm{Md}$ of earthquakes was evaluated by using the duration of seismic waves [Tsumura, 1967].

[7] Because the seismic velocity structure strongly varies perpendicularly to the subduction zone, the 


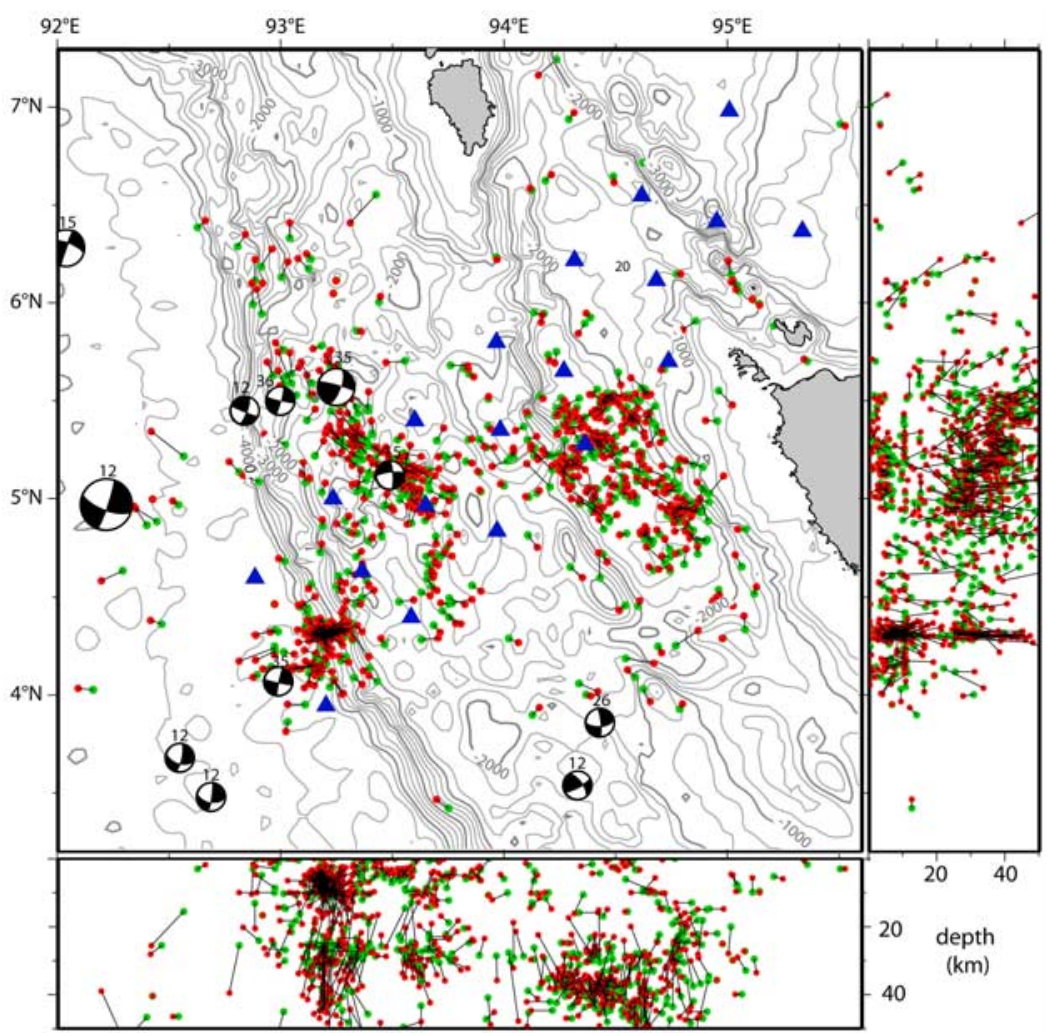

Figure 3. Aftershocks distribution before and after the relocation. Green and red dots show earthquakes located with the 1-D and 3-D velocity models, respectively. Focal mechanism of strike-slip earthquakes in the oceanic crust and the overlying wedge are from the Harvard catalog. Numbers above beach balls are the depths of earthquakes in $\mathrm{km}$. E-W and $\mathrm{N}-\mathrm{S}$ vertical cross sections of the aftershocks distribution are shown.

1-D seismic velocity structure was not sufficiently accurate for a precise hypocenter determination (green dots in Figure 3). A 3-D velocity model is required to obtain more accurate hypocenter locations. In addition, in a complex geological environment, a realistic $\mathrm{Vp} / \mathrm{Vs}$ structure must be used to accurately determine hypocenters. As the hypocenter depth determinations largely depend on $\mathrm{Vp} /$ Vs ratios [e.g., Obana et al., 2001], we operated the SIMUL2000 program [Thurber and EberhartPhillips, 1999], which use true stations depths and relocate earthquakes with a 3-D P wave velocity model and a $\mathrm{Vp} / \mathrm{Vs}$ model established by using the $\mathrm{Vp}$ and $\mathrm{Vs}$ residual time arrivals to calculate the $\mathrm{Vp} / \mathrm{Vs}$ ratios.

[8] The 3-D initial model was obtained by modifying the slab geometry given by Gudmundsson and Sambridge [1998] with the aftershock distribution recorded by the Japanese OBS network [Araki et al., 2006] for depths shallower than $60 \mathrm{~km}$. We assumed the thicknesses of the oceanic and continental crusts are 7 and $25 \mathrm{~km}$ respectively. The thickness of the sedimentary layer was deter- mined by using available seismic data in the area. The $\mathrm{P}$ wave velocities of the oceanic and continental crusts were assumed to be 6.5 and $6.2 \mathrm{~km} / \mathrm{s}$, respectively. The velocity for the upper mantle was set up at $8.1 \mathrm{~km} / \mathrm{s}$ and at $2.2 \mathrm{~km} / \mathrm{s}$ for the sedimentary cover.

[9] A total of $4,461 \mathrm{P}$ wave and $3,471 \mathrm{~S}$ wave arrival times were determined and 858 earthquakes were relocated. Figure 3 shows the distribution of earthquakes localized with the 1-D velocity model (green dots) and the 3-D velocity model (red dots). The average RMS residuals decrease from 0.230 to $0.107 \mathrm{~s}$. As expected, the relocation does not significantly affect the geographical position of epicenters but rather affects the depth of hypocenters. Though they correspond to the distance between hypocenter locations obtained by using 1-D and 3-D velocity models, the "error bars" give an indication of the expected errors in hypocenter locations as they correspond to two extreme velocity models. The relocation of $87 \%$ and $95 \%$ of the seismic events is smaller than $5 \mathrm{~km}$ and $25 \mathrm{~km}$ in the three directions respectively, suggesting the 


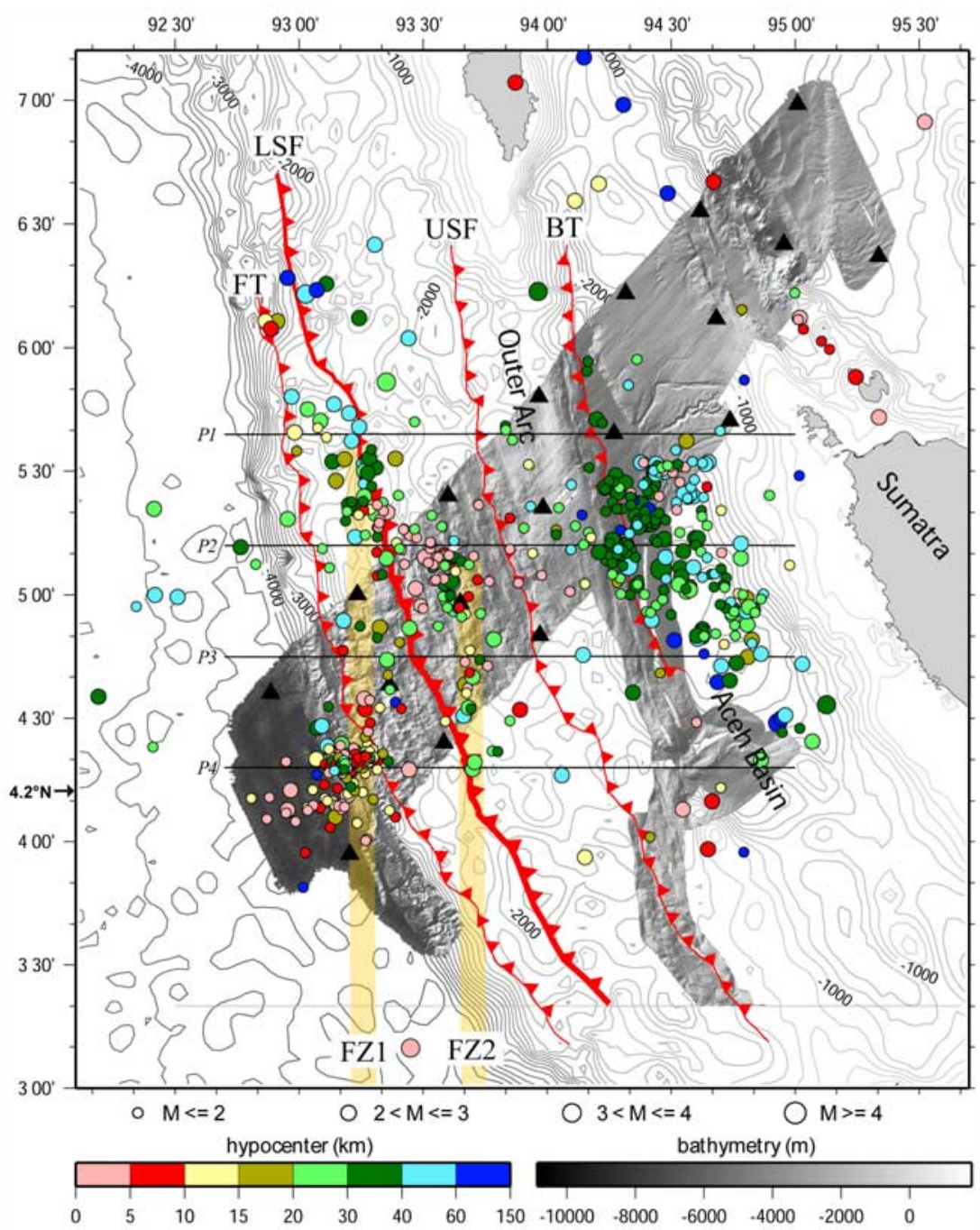

Figure 4. Hypocenters of 858 microearthquakes recorded in the northwestern Sumatra by the OBS network during 12 days and relocated with the SIMUL2000 program [Thurber and Eberhart-Phillips, 1999]. The size of dots is function of the magnitude. Colors show the depth ranges. Bathymetric contours every $200 \mathrm{~m}$. Shaded zone shows the detailed bathymetry [Sibuet et al., 2007]. Black triangles correspond to the locations of OBS stations. Red lines with triangles show the main thrusts determined from the multibeam and $3.5 \mathrm{kHz}$ echo sounder data (Rangin et al., submitted manuscript, 2008). The E-W black lines (P1 to P4) are the locations of the four cross sections shown in Figure 6. FT, Frontal Thrust; LSF, Lower Splay Fault; USF, Upper Splay Fault; BT, Backstop Thrust.

accuracy of localization is good enough to ensure our interpretations.

\section{Relocation of Earthquakes and Distribution of Hypocenters}

\subsection{Location of Hypocenters}

[10] The aftershock activity is localized in two domains (Figure 4):

[11] 1. Beneath the Aceh basin and fore arc, most of the earthquakes are located between 30 and $50 \mathrm{~km}$ and are trending along the NW-SE direc- tion, parallel to the trench direction. The cluster of earthquake disappears abruptly at $\sim 5.7^{\circ} \mathrm{N}$ latitude. The disappearance of aftershocks north of this latitude was already noticed by Engdahl et al. [2007] and Dewey et al. [2007] and probably corresponds to changes in the physical properties across the plate interface [Kennett and Cummins, 2005] defined as the boundary between the subducting lower plate and the upper plate. On the basis of kinematics and global tomographic studies, the subduction slab has a downdip limit much deeper than $50 \mathrm{~km}$ and extends well into the mantle in this region. 


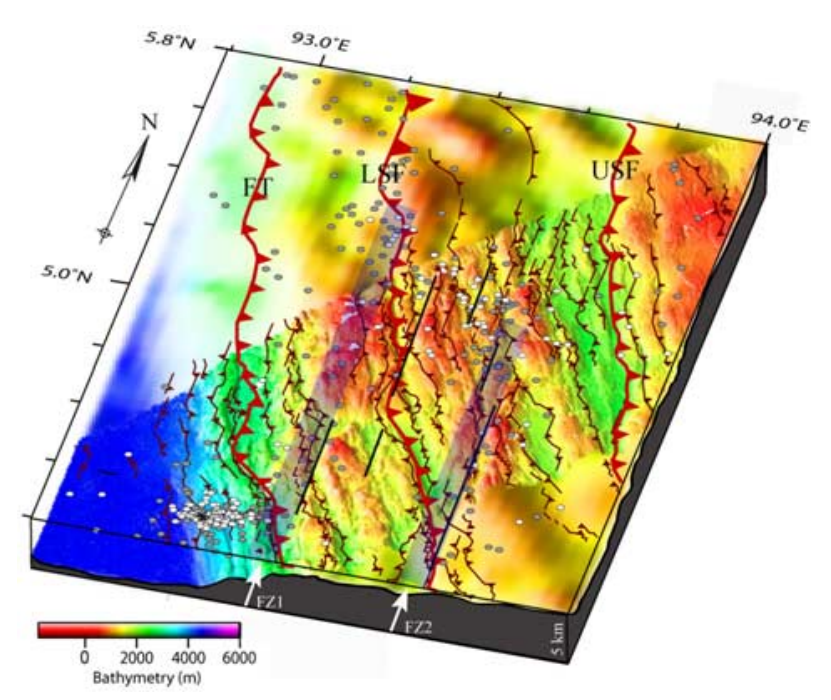

Figure 5. Detailed structural interpretation of the upper part of the accretionary wedge located southwest of the Outer Arc. The two light broad N-S trending gray lines are the locations of $\mathrm{N}-\mathrm{S}$ fracture zones FZ1 and FZ2 recognized from the aftershocks distribution. Black lines are $\mathrm{N}-\mathrm{S}$ trending valleys of the wedge linked to $\mathrm{N}-\mathrm{S}$ fracture zone features of the lower plate [Sibuet et al., 2007]. Dark red lines with triangles are thrust faults. Thick continuous red lines with triangles are main thrusts (Rangin et al., submitted manuscript, 2008) determined from swath bathymetric and $3.5 \mathrm{kHz}$ data. White and gray dots show earthquakes shallower and deeper than $7 \mathrm{~km}$, respectively. The earthquake location is projected to the surface. Light from the northwest. FT, Frontal Thrust; LSF, Lower Splay Fault; USF, Upper Splay Fault; BT, Backstop Thrust.

[12] 2. From the Sunda Trench to the Outer Arc, most of aftershocks are shallower than $40 \mathrm{~km}$, except for two $\mathrm{N}-\mathrm{S}$ trending clusters of aftershocks, ranging from the sea bottom to $50 \mathrm{~km}$ depth and lying along the $93.2^{\circ} \mathrm{E}$ and $93.6^{\circ} \mathrm{E}$ meridians (Figure 4). To the north, the seismicity seems to disappear along FZ1 near the $5.7^{\circ} \mathrm{N}$ as mentioned by several former works [Kennett and Cummins, 2005; Dewey et al., 2007; Engdahl et al., 2007], but we have to be cautious as this limit is well outside the OBS network. However, along FZ2, the $\mathrm{N}-\mathrm{S}$ trending seismicity disappears at $5.3^{\circ} \mathrm{N}$, in an area located within the OBS network, suggesting that the cessation of aftershock activity is real. A N-S trending earthquake distribution located in the lower plate was also shown by Fauzi et al. [1996] and Abercrombie et al. [2003] in the northern prolongation of Investigator FZ and related to this $\mathrm{N}-\mathrm{S}$ oceanic fracture zone. In consequence, the two swarms of events located along the $\mathrm{N}-\mathrm{S}$ direction in our study area (FZ1 and FZ2, light yellow lines in Figure 4) can be linked to left- lateral strike-slip reactivated portions of lower plate fracture zones, which correspond to the northward prolongation of fractures zones identified by Deplus et al. [1998]. The $3.5 \mathrm{kHz}$ profiles and swath bathymetric data show several N-S oriented valleys overlying these earthquake clusters (Figure 5) suggesting that the structural fabric of the overlying portion of wedge is affected by the lower plate active fracture zones [Sibuet et al., 2007; Graindorge et al., 2008; X. Le Pichon, Le séisme de Sumatra du 26 décembre 2004 et la subduction Indo-Australienne, Cours du Collège de France, Chaire de Géodynamique, Cours et Séminaires, 2005-2006, http://www.cdf.u-3mrs.fr/ lepichon/]. Detailed 3-D swath bathymetric images of these N$\mathrm{S}$ trending valleys are beautifully displayed by Sibuet et al. [2007]. N-S oriented topographic lineaments were also observed in the oceanic domain, just southwest of the Sunda trench with active strike-slip deformation suggested by the presence of up to $20-30 \mathrm{~m}$ vertical offset in swath bathymetric and $3.5 \mathrm{kHz}$ data [Graindorge et al., 2008]. In addition, the intersection of these $\mathrm{N}-\mathrm{S}$ elongated bathymetric features with the accretionary wedge partly controls the geometry of thrust anticlines and the location of erosional features at the wedge toe. This suggests that these $\mathrm{N}-\mathrm{S}$ oceanic lineaments have a significant impact on the wedge toe but also further landward in the wedge [Graindorge et al., 2008].

[13] In the vicinity of the wedge toe, along the $93.2^{\circ} \mathrm{E}$ meridian, we have identified a cluster of small earthquakes, which were only recorded on the five deepest OBS stations. As events in the Wharton Basin belong to the lower plate, the swarm of events located immediately NE of the trench, beneath the wedge toe, is also related to the lower plate postseismic activity [Sibuet et al., 2007]. The shallow earthquakes located further north in the wedge above this active fracture zone may thus result from the interaction of the $\mathrm{N}-\mathrm{S}$ lower plate deformation with the overlying prism toe.

\subsection{Cross Sections}

[14] Four E-W vertical cross sections are shown in Figure 6 (P1 to P4). Only events with relocation uncertainties smaller than $5 \mathrm{~km}$ in the three directions are displayed. In Figure 6, the uncertainties of localization are shown by "error bars," which are generally smaller than the size of the dots. West of $93.7^{\circ} \mathrm{E}$, the vertical distribution of earthquakes shows that they belong to two N-S 25-km-wide stripes located along the $93.2^{\circ} \mathrm{E}$ and $93.7^{\circ} \mathrm{E}$ meri- 


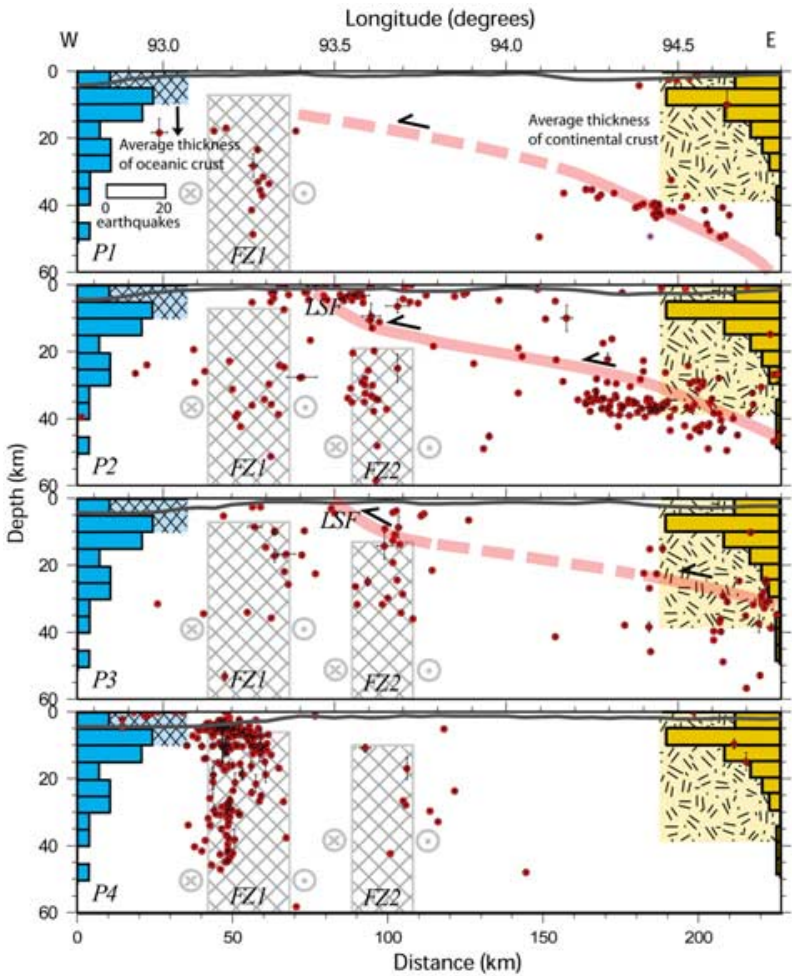

Figure 6. Aftershocks projected from $25 \mathrm{~km}$ on each side of cross sections P1 to P4 located in Figure 4. Red dots show the positions of aftershocks. The error bars are relocation uncertainties in the vertical and horizontal direction. The solid gray lines show the bathymetry. The light red lines show the position of the plate interface and the LSF evidenced by the aftershock distribution. Gray cross-hatched boxes show the locations of active $\mathrm{N}-\mathrm{S}$ fracture zones FZ1 and FZ2 recognized from the aftershock distribution. The histograms along the $y$ axes show the seismogenic layer thickness Ts for the oceanic and continental lithospheres on the left- and right-hand side of cross sections. LSF, Lower Splay Fault.

dians. Seismic events extend from the sea bottom to $50 \mathrm{~km}$, a depth which does not significantly exceeds the thickness Ts of the oceanic seismogenic layer. Along the left-hand side of Figure 6 are plotted the histograms of the depth of oceanic intraplate earthquakes [Watts and Burov, 2003]. As Ts $(50 \mathrm{~km})$ largely exceeds the average thickness of the oceanic crust (about $10 \mathrm{~km}$ ), it is worthwhile to record earthquakes within the suboceanic mantle, beneath the two oceanic fracture zones. Fracture zone FZ1 can be traced on all four profiles but fracture zone FZ2 identified on profiles P4 to P2 is no more active at its intersection with profile P1. If we compare the distribution of hypocenters with respect to the location of the plate interface determined by Gudmundsson and Sambridge [1998] and Araki et al. [2006], seismic events related to the two fracture zones are located beneath and above the plate interface. Within the lower plate (depth $>10 \mathrm{~km}$ ), the two groups of earthquakes associated with FZ1 and FZ2 are distinct. However, between distances 60 and $80 \mathrm{~km}$ on profile P2 (Figure 6) and in plane view (Figure 4), a cluster of earthquakes shallower than $5 \mathrm{~km}$ (pink dots near $5.1^{\circ} \mathrm{N}$ seems to connect the northern end of the active portion of FZ2 to FZ1 within the upper plate. These shallow earthquakes underline the existence of a dextral upper plate wrenched pattern in the wedge toe. It suggests that the lower plate stress accumulated along FZ1 and FZ2 is released in the overlying wedge not only above the fracture zones but also in between.

[15] After large earthquakes, postseismic deformation may result from earthquake-induced slip along the plate interface as shown for the 2005 Nias earthquake [Hsu et al., 2006]. It is what we observe in the eastern parts of profiles P1 to P4. The afterslip seismicity delineates the 15-20 degrees dipping plate interface, which position corresponds to the upper limit of the aftershocks recorded by the teleseismic and OBS stations [Araki et al., 2006; Dewey et al., 2007; Engdahl et al., 2007]. A group of earthquakes that become shallower westward of the subduction megathrust fault and merges the sea bottom at a steep angle is probably related to the Lower Splay Fault, a main $\mathrm{N} 10^{\circ} \mathrm{W}$ thrust mapped from the bathymetry and echo sounder data (pink lines in Figure 6) [Sibuet et al., 2007; C. Rangin et al., Docked or accreted Indian Ocean Fracture Ridges along the Sumatra subduction zone northern tip, submitted to Geochemistry Geophysics Geosystems, 2008].

\subsection{Comparison With Earthquakes Located by the Japanese OBS Network}

[16] In February-March 2005, 17 short-term instruments were deployed during 19-22 days in a small area adjacent to our transect [Araki et al., 2006] (blue dots in Figure 7). The 1100 published hypocenters of the Japanese experiment are displayed together with our 858 relocated hypocenters in Figure 7a. All relocated earthquakes with relocation distance smaller than $5 \mathrm{~km}$ in the three directions are projected along the cross section AB. In plane view, the Japanese data show a similar pattern than our data: a NW-SE trending feature at the plate interface below the fore arc and $\sim \mathrm{N}-\mathrm{S}$ directions in the west. By using the relocated earthquakes recorded by the two networks, the active portion of fracture zone FZ2 can be traced southward inside the Japanese network. 

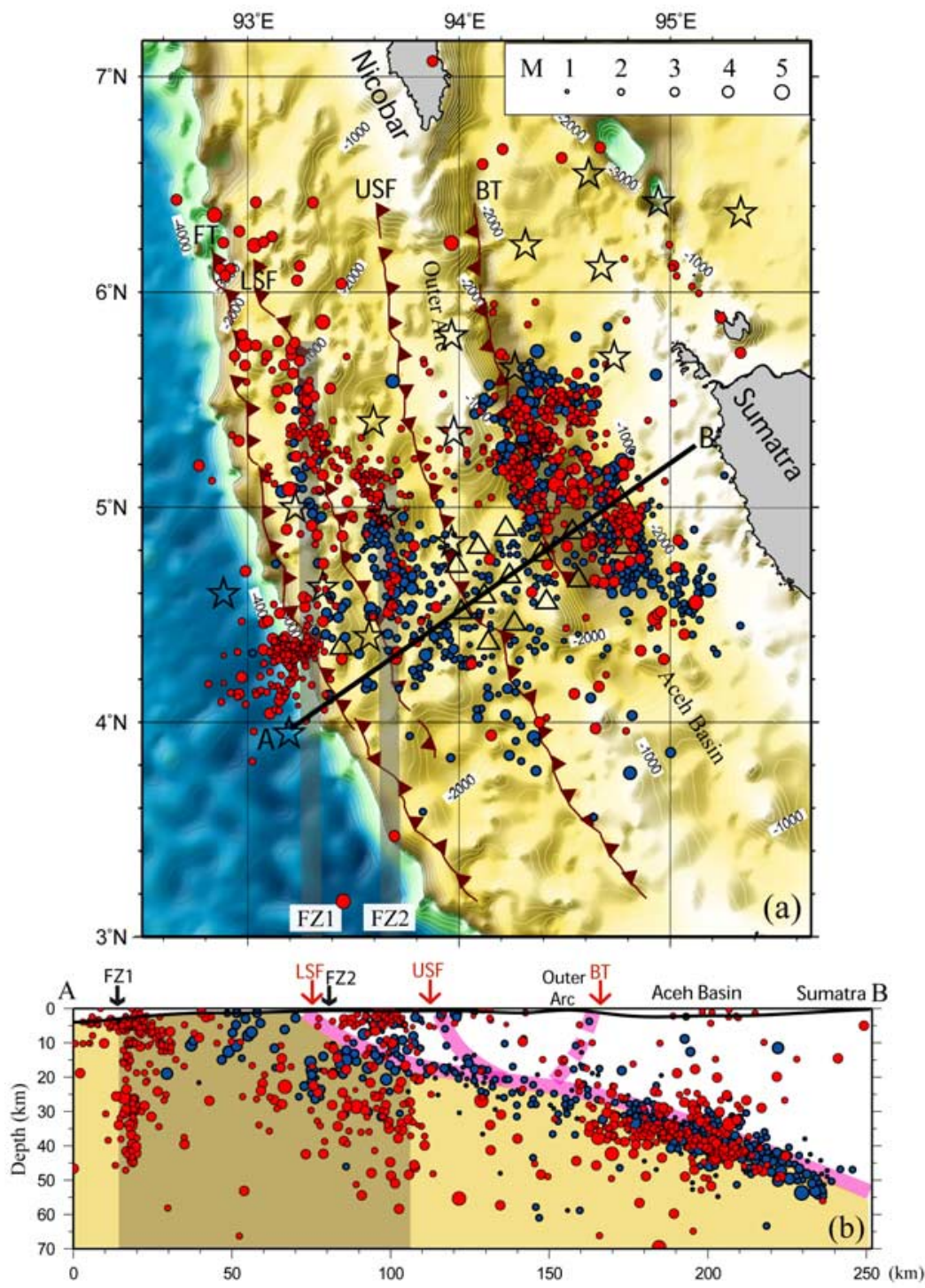

Figure 7. (a) Aftershock determinations from the two Japanese and French networks of seismometers. In blue, aftershocks determined during 10 days of recording period (20 February to 13 March 2005) by Araki et al. [2006] using 17 seismometers (triangles). In red, 858 aftershocks determined from our survey using 20 seismometers (stars) from 22 July 2005 to 3 August 2005. (b) Seismicity along profile AB. All relocated earthquakes with relocation distance smaller than $5 \mathrm{~km}$ in the three directions are projected along the cross section $\mathrm{AB}$. Black arrows show the position of FZ1 and FZ2 in the profile. The dark zone between 15 and $115 \mathrm{~km}$ shows where the seismicity of the two $\mathrm{N}-\mathrm{S}$ features is projected. In pink, slab and thrust faults deduced from the distribution of aftershocks.

However, the active portion of fracture zone FZ1 cannot be extended to the south as it is located outside of the Japanese network. The aftershock hypocenters projected on the cross section $\mathrm{AB}$ (Figure $7 \mathrm{~b}$ ) show the vertical distribution of earthquakes between the trench $(0 \mathrm{~km})$ and $250 \mathrm{~km}$. The whole set of data shows that the active portion of fracture zone FZ2 can be extended southward to $4.2^{\circ} \mathrm{N}$ and that aftershocks along the plate interface (between 80 and $240 \mathrm{~km}$ ) seem to disappear west of FZ2 $\left(93.7^{\circ} \mathrm{E}\right)$. If the plate interface is clearly delineated by the aftershock seismicity east of
$80 \mathrm{~km}$, however there is no clear postseismic activity from $80 \mathrm{~km}$ to the trench along the expected location of the plate interface. This lack of seismicity only indicates that this portion of plate interface, if it exists, was aseismic or partly aseismic during the recording time periods. This portion of plate interface was also inactive during the 2004 great Sumatra-Andaman earthquake for three reasons: (1) The coseismic slip was null west of a limit located between the USF and LSF [Chlieh et al., 2007]. (2) High-resolution seismic reflection profiles acquired across a portion of the 
frontal deformation zone and adjacent oceanic domain in the area of our survey does not show any single, laterally extensive structural offset at the deformation front that might be interpreted as contributing to the 2004 tsunami [Mosher et al., 2008]. (3) Swath bathymetric data imaged small recent scars and deposits at the toe wedge whose size was incompatible with a significant coseismic slip in this region [Sibuet et al., 2007]. In situ pore pressure measurements using the Ifremer piezometer and coring in the largest scar, of modest size [Henstock et al., 2006], demonstrate that high excess pore pressure and sediment deformation were generated by the shaking associated with the 2004 great Sumatra-Andaman earthquake and was not due to an underlying large coseismic slip [Sultan et al., 2009]. In the hypothesis of a coseismic rupture joining the trench, the superficial deformation in the wedge toe would have been more catastrophic than the one observed and the tsunami less damaging.

[17] The earthquake cluster on the prism toe along the $93.2^{\circ} \mathrm{E}$ meridian was not recorded by the Japanese OBSs because these earthquakes are too small and too far from their OBS network to be recorded. Between 80 and $240 \mathrm{~km}$, the seismicity recorded by the two networks is similar and clearly underlines the plate interface. At $80 \mathrm{~km}$, a cluster of earthquakes joins the plate interface to the sea bottom, and seems to reactivate a preexisting thrust fault (pink lines in Figure 7b), the Lower Splay Fault already identified on the sea bottom from the swath bathymetric and echo sounder data [Sibuet et al., 2007; Rangin et al., submitted manuscript, 2008]. At 120 and $160 \mathrm{~km}$, two minor clusters of earthquakes might follow the Upper Splay Fault and Backstop Thrust (pink lines in Figure 7b) also identified from the swath bathymetric and echo sounder data [Sibuet et al., 2007; Rangin et al., submitted manuscript, 2008], suggesting that the USF could have been alternatively the active splay fault during the 2004 great Sumatra-Andaman earthquake. This hypothesis seems to be unlikely as the megathrust is still imaged by the aftershocks between the LSF and USF. One possibility to solve this problem was to look at tsunami simulations. However, for the moment, it is impossible to decipher if the megathrust branched updip onto the LSF or the USF [Hirata et al., 2008].

[18] To conclude, the well-developed seismicity along the plate interface between depths of 30 and $60 \mathrm{~km}$ with a dip angle of $\sim 15-20^{\circ}$ is similar to the one observed along other intercontinental megathrusts. The disappearance of the deep postseismic activity north of $5.7^{\circ} \mathrm{N}$ might correspond to changes in the physical properties of the plate interface as mentioned by several former studies [Kennett and Cummins, 2005; Dewey et al., 2007; Engdahl et al., 2007] or to changes in afterslip strain accumulation.

[19] The two N-S trending swarms of events suggest that the aftershock activity is linked to the left-lateral strike-slip motion along two fracture zones located at $93.2^{\circ} \mathrm{E}$ and $93.6^{\circ} \mathrm{E}$, which influences the distribution of the aftershock activity within the accretionary wedge.

[20] Within the upper plate, inside of the wedge, the distribution of aftershocks is concentrated in three types of domains: (1) domains where the two aftershocks clusters correspond to the two portions of active $\mathrm{N}-\mathrm{S}$ fracture zones, (2) the domain connecting the northern end of the active portion of FZ2 to FZ1 and corresponding to earthquakes shallower than $5 \mathrm{~km}$ (Figure 4) that we attribute to dextral wrenching, and (3) possibly the domains of the two LSF and USF thrust faults where aftershocks seem to join the plate interface to the sea bottom at a steep angle.

\section{Discussion}

[21] The great Sumatra-Andaman earthquake changed the stress distribution at the plate interface and in the upper plate, triggering deformations in the overlying upper plate. However, earthquakes occurring along the $\mathrm{N}-\mathrm{S}$ lower plate fracture zones are presumably linked to the differential stress accumulation along the diffuse India/Australia plate boundary, which corresponds to a westward decrease of plate velocity in a $\sim 1000-\mathrm{km}$-wide stripe of oceanic crust from $10 \mathrm{~mm} / \mathrm{a}$ at the Investigator FZ to zero at the Ninety East Ridge [Delescluse and Chamot-Rooke, 2007]. In the following discussion, we will try to understand how the strike-slip motion along the fracture zones may induce deformation inside the wedge.

[22] The discussion is based on the interpretation of multibeam and echo sounder data acquired during the "Sumatra Aftershocks" cruise [Sibuet et al., 2007] and following cruises [Graindorge et al., 2008], the deep penetration MCS profiles performed during a BGR cruise [Gaedicke and Neben, 2006], and a detailed geological study performed by Rangin et al. (submitted manuscript, 2008) (Figure 5). On the basis of swath bathymetric maps [Sibuet et al., 2007; Henstock et al., 2006; 
Moran et al., 2005; Soh et al., 2005; Graindorge et al., 2008] and echo sounder and multichannel seismic data [Sibuet et al., 2007; Graindorge et al., 2008; Mosher et al., 2008; Gaedicke and Neben, 2006; Rangin et al., submitted manuscript, 2008], the vergency of the folds has been determined from the asymmetry of the wedge anticlines. Morphologically, the wedge displays sinuous $\mathrm{N} 30^{\circ} \mathrm{W}$ elongated sedimentary ridges and valleys interrupted by $\mathrm{N}-\mathrm{S}$ trending depressions [Sibuet et $a l ., 2007]$. Submeridian dextral wrenching is dominant in the wedge with $\mathrm{N} 10^{\circ} \mathrm{W}$ trending dextral faults, in particular in the area overlying the $\mathrm{N}-\mathrm{S}$ active lower plate fracture zones. Focal mechanisms of strike-slip earthquakes were extracted from the Harvard catalog (Figure 3). Eight focal mechanisms show left-lateral strike-slip events occurring in the oceanic domain of the Wharton Basin and in the subducting lower plate. Three upper plate focal mechanisms show right-lateral strike-slip events in the upper plate. We suggest that the right-lateral wrenched tectonic fabric of the wedge is triggered by the $\mathrm{N}-\mathrm{S}$ lower plate leftlateral strike-slip deformation as already mentioned [Sibuet et al., 2007; X. Le Pichon, Le séisme de Sumatra du 26 décembre 2004 et la subduction Indo-Australienne, Cours du Collège de France, Chaire de Géodynamique, Cours et Séminaires, 2005-2006, http://www.cdf.u-3mrs.fr/ lepichon/ ]. Three main $\mathrm{N} 10^{\circ} \mathrm{W}$ dextral wrenched fault zones with westward vergency are mapped: the Frontal Thrust (FT), the Lower Splay Fault (LSF), and the Upper Splay Fault (USF) (Figures 4, 5, and 7). Rangin et al. (submitted manuscript, 2008) have established the structural correlation between the superficial depth sections and the deep reflectors identified on MCS profile BGR-101 cutting across the surveyed area. The Lower and Upper Splay Faults are imaged from the sea bottom into the basement. However, the intense strike-slip deformation is only observed in two areas beneath the LSF (Figure 5): In the south, where the LSF follows the $93.6^{\circ} \mathrm{E} \mathrm{N}-\mathrm{S}$ valley above an active portion of $\mathrm{FZ2}$, between $4.2^{\circ} \mathrm{N}$ and $4.4^{\circ} \mathrm{N}$ (Figures 4 and 5); In the north, the LSF follows a northerly direction already underlined by a bathymetric trend in the Sandwell and Smith [1994] map between $5.1^{\circ} \mathrm{N}$ and $5.4^{\circ} \mathrm{N}$, above an active portion of FZ1. In between the LSF also follows another northerly direction (Figure 5) not presently associated with a present-day active portion of underlying fracture zone. Thus, within the wedge, we can correlate the $\mathrm{N}-\mathrm{S}$ segments of the LSF, generally marked by $\mathrm{N}-\mathrm{S}$ valleys, to underlying portions of active or inactive fracture zones (Figure 5). These observations provide a general explanation for the sigmoïdal pattern of the thrust faults within the wedge. The $\mathrm{N} 10^{\circ} \mathrm{W}$ thrust faults consist of $\mathrm{N}-\mathrm{S}$ segments above the $\mathrm{N}-\mathrm{S}$ fracture zones and connecting $\sim \mathrm{NW}-\mathrm{SE}$ segments. As a result the partitioning of the India-Australia/Sunda motion within the wedge occurs along combined $\mathrm{N}-\mathrm{S}$ and $\sim \mathrm{NW}-\mathrm{SE}$ directions and not as previously said simply along a direction parallel to the Sumatra fault [e.g., Fitch, 1972; McCaffrey, 1992; Sieh and Natawidjaja, 2000].

[23] Thus inside the wedge, the shape of thrusts is influenced by the deformation of the lower plate and is not only due to the conventional wedge shortening due to the subduction process. This is also supported by the fact that the plate interface does not outcrop west of the prism toe [Mosher et al., 2008] and cannot be identified in the first $80 \mathrm{~km}$ from the trench (Figure $7 \mathrm{~b}$ ). If this is true, the distal part of the wedge consists of sediment ridges not yet incorporated within the upper plate and the present-day frontal thrust, i.e., the outcrop of the subduction megathrust fault, is located inside the wedge, probably along the LSF.

[24] Figure 8 shows the free air gravity anomalies in our study area. An unusually high NNW-SSE trending gravity anomaly lies over the distal part of the wedge where the postseismic active portions of oceanic fracture zones have been identified and disappears north of $5.8^{\circ} \mathrm{N}$ latitude, where the aftershocks seismicity also abruptly decreases. So, the region of high free air gravity anomalies corresponds to the region of postseismic active fracture zones identified beneath the toe of the wedge. This relatively high free air anomaly suggests that this area is isostatically undercompensated. Such a relatively high free air gravity anomaly was also observed in the lower wedge region where the Investigator FZ subducts below the Sumatra wedge [Fauzi et al., 1996].

[25] Several studies concerning the coseismic slip distribution of the Sumatra-Andaman earthquake have been performed by different approaches [Ammon et al., 2005; Banerjee et al., 2005; Lay et al., 2005; Vigny et al., 2005; Subarya et al., 2006; Chlieh et al., 2007]. In Figure 8, the coseismic slip contours calculated by Chlieh et al. [2007] on the basis of a detailed joint seismic-geodetic determination have been added. The curve of null coseismic slip remarkably follows the landward side of the positive gravity anomaly and then, north of $6.5^{\circ} \mathrm{N}$, turns to the west and follows the trench. All the coseismic slip occurs east of the 


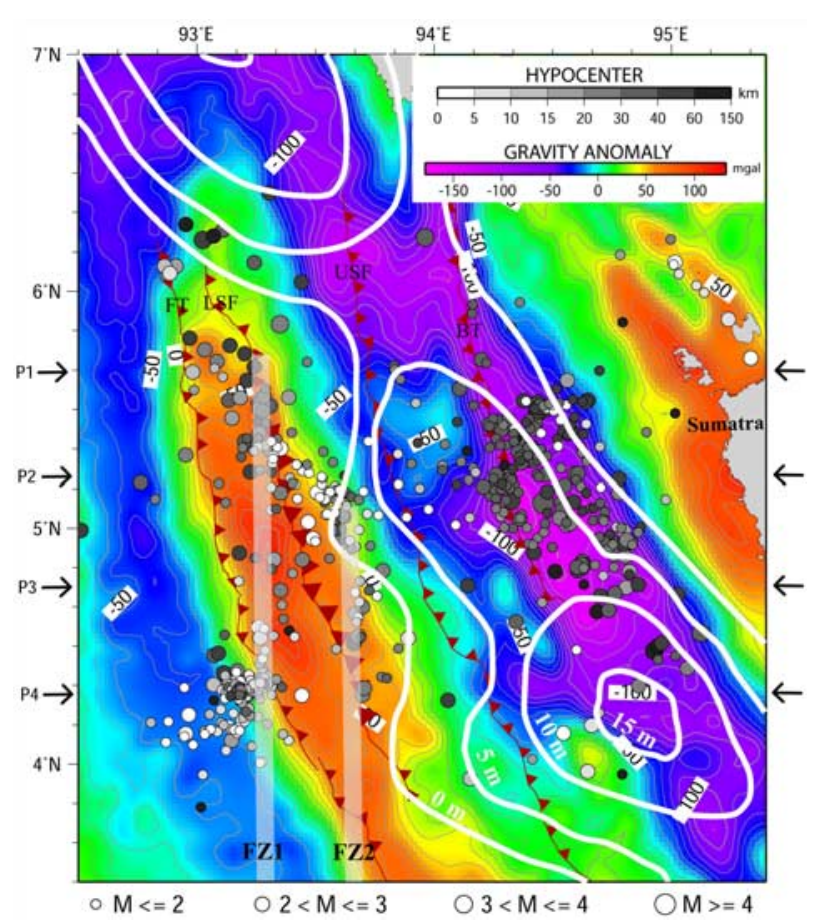

Figure 8. Free air gravity anomaly map of the Sumatra-Andaman trench. Dots show the positions of epicenters. The size of dots is function of the magnitude. Relatively high free air gravity anomalies are observed in the area where $\mathrm{N}-\mathrm{S}$ fracture zones FZ1 and FZ2 are active. Coseismic slip contours every $5 \mathrm{~m}$ in white from Chlieh et al. [2007]. Black arrows show the position of the four profiles located in Figure 4.

active portions of oceanic fracture zones FZ1 and FZ2 confirming that the subduction megathrust fault does not rupture all the way to the toe of the wedge. Thus, during the 2004 great SumatraAndaman earthquake, these portions of active oceanic fracture zones and the overlying portion of distal wedge might have played the role of barrier that forced the coseismic slip to ramp upward along a splay fault located in the area of the highly decreasing or null coseismic slip. Numerous works in Nankai Trough also show that the subducted oceanic crust might be strongly mechanically coupled with the toe of the wedge and may play a significant role as a seaward barrier inhibiting the coseismic slip to propagate farther seaward [Kodaira et al., 2000; Nakanishi et al., 2002]. Thus, the coseismic slip, which follows the plate interface should rise into the sea bottom along a splay fault as proposed by Wang and Hu [2006] and G. Plafker et al. (Evidence for a secondary tectonic source for the cataclysmic tsunami of $12 / 26 / 2004$ on NW Sumatra, paper presented at
Annual Meeting, Seismological Society of America, Kona, Hawaii, 11-13 April 2007). Such displacement along a splay fault was observed during the 1964 Alaskan earthquake in the Patton Bay [Plafker, 1972], the 1946 Nankai earthquake in the Nankai subduction system [Cummins and Kaneda, 2000; Park et al., 2002], the 1958 earthquake on the Ecuador margin [Collot et al., 2004] and inferred where the 2005 Nias earthquake occurred [Hsu et al., 2006]. On the basis of deep MCS profiles, Moore et al. [2007] showed in the Nankai subduction zone the image of such a megasplay thrust system, rising from the plate interface to the seafloor along a splay fault. The progressively steepened splay fault increases the potential for vertical uplift with large slip contributing to generate devastating tsunamis. Thus, we propose that during the 2004 great Sumatra-Andaman earthquake, the plate interface rupture was transferred to the sea bottom along a splay fault, probably the LSF, though we cannot fully exclude the USF, and that it was the main factor controlling the large amplitude of the tsunami.

[26] Several studies show that the rupture process for the 2004 great Sumatra-Andaman earthquake strongly changed of strike and rupture properties near $6^{\circ} \mathrm{N}$ [Kennett and Cummins, 2005; Stein and Okal, 2005; Ishii et al., 2005; Gahalaut et al., 2006; Nuannin et al., 2005; Pollitz et al., 2006; Pietrzak et al., 2007]. The transition zone from rapid slip to dominantly slower slip reported north of $6^{\circ} \mathrm{N}$ [Bilham, 2005] coincided with the northern end of the $\mathrm{N}-\mathrm{S}$ active fracture zones.

\section{Conclusions}

[27] The main conclusions of this study are illustrated in the sketch of Figure 9: the group of aftershocks observed beneath the Aceh basin and fore arc delineates the rupture zone. The sudden stop of this earthquake cluster at $5.7^{\circ} \mathrm{N}$ may correspond to changes in the physical properties of the slab interface. Alternatively, if this cluster is the result of afterslip its disappearance northward may be related to change in the strain accumulation.

[28] Two clusters of earthquakes, trending $\mathrm{N}-\mathrm{S}$ between 10 and $50 \mathrm{~km}$ in depth, are located below the toe of the wedge and in the prolongation of N$\mathrm{S}$ oceanic fracture zones along the 93.2 and $93.7^{\circ} \mathrm{E}$ meridians (FZ1 and FZ2, light gray lines in Figure 9). These active oceanic fracture zones and the overlying sediments of the wedge may have played the 


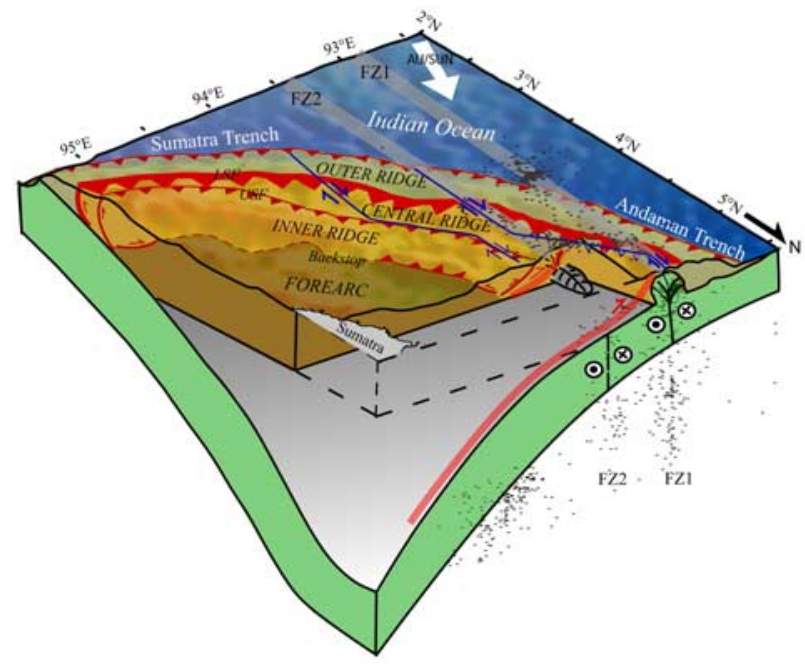

Figure 9. Diagram showing a 3-D view of the Sumatra-Andaman subduction system. White arrow indicates the Australia/Sunda plate motion. 858 relocated aftershocks were projected to the surface (dark gray dots) and vertically along $5.6^{\circ} \mathrm{N}$ (black crosses). Light gray lines show the surface projection of the $\mathrm{N}-\mathrm{S}$ trending oceanic fracture zones FZ1 and FZ2. Red lines are the main submeridian dextral wrenched fault zones determined from the interpretation of multibeam and echo sounder data. Blue lines show the $\mathrm{N} 10^{\circ} \mathrm{W}$ trending dextral pattern partly overlying the area where $\mathrm{N}-\mathrm{S}$ leftlateral strike-slip fracture zones are present (Rangin et al., submitted manuscript, 2008). Light red line shows the position of the coseismic 2004 rupture zone.

role of barrier for the coseismic rupture of the 2004 great Sumatra-Andaman earthquake. The thrust features determined in the upper plate are dominated by the N-S and NNW-SSE trending directions (red lines with triangles and purple lines), which show the influence of the underlying active oceanic fracture zones on the structure of the upper plate. The dextral wrenched system of thrust faults within the wedge (blue lines) would be linked to the differential stress accumulation along fracture zones of the diffuse India/Australia plate boundary. The relatively high free air gravity anomalies, the coseismic slip distribution and the geological structural pattern are the testimony of active underlying fracture zones (Figure 9). We propose that the rupture zone does not emerge at the trench but instead ramps upward along the Lower Splay fault (broad red lines in Figure 9).

\section{Acknowledgments}

[29] We thank the captain and crew of the R/V Marion Dufresne for their help during the cruise. We also thank the Associate Editor and D. Schaff for their careful reviews and very helpful comments. The GMT software package was used to draw Figures 1-9 [Wessel and Smith, 1991].

\section{References}

Abercrombie, R. E., M. Antolik, and G. Ekstrom (2003), The June $2000 M_{w} 7.9$ earthquakes south of Sumatra: Deformation in the India-Australia Plate, J. Geophys. Res., 108(B1), 2018, doi:10.1029/2001JB000674.

Ammon, C. J., et al. (2005), Rupture process of the 2004 Sumatra-Andaman earthquake, Science, 308(5725), 11331139, doi:10.1126/science. 1112260 .

Araki, E., M. Shinohara, K. Obana, T. Yamada, Y. Kaneda, T. Kanazawa, and K. Suyehiro (2006), Aftershock distribution of the 26 December 2004 Sumatra-Andaman earthquake from ocean bottom seismographic observation, Earth Planets Space, 58(2), 113-119.

Banerjee, P., F. F. Pollitz, and R. Burgmann (2005), The size and duration of the Sumatra-Andaman earthquake from farfield static offsets, Science, 308(5729), 1769-1772, doi:10.1126/science.1113746.

Barckhausen, U. (2006), The segmentation of the subduction zone offshore Sumatra: Relations between upper and lower plate, Eos Trans. AGU, 87(52), Fall Meet. Suppl., Abstract U53A-0029.

Bilham, R. (2005), A flying start, then a slow slip, Science, 308(5725), 1126-1127, doi:10.1126/science.1113363.

Bock, Y., L. Prawirodirdjo, J. F. Genrich, C. W. Stevens, R. McCaffrey, C. Subarya, S. S. O. Puntodewo, and E. Calais (2003), Crustal motion in Indonesia from Global Positioning System measurements, J. Geophys. Res., 108(B8), 2367, doi:10.1029/2001JB000324.

Briggs, R. W., et al. (2006), Deformation and slip along the Sunda Megathrust in the great 2005 Nias-Simeulue earthquake, Science, 311(5769), 1897-1901, doi:10.1126/ science. 1122602 .

Chlieh, M., et al. (2007), Coseismic slip and afterslip of the great $M_{w} 9.15$ Sumatra-Andaman earthquake of 2004, Bull. Seismol. Soc. Am., 97(1A), S152-S173, doi:10.1785/ 0120050631.

Collot, J.-Y, B. Marcaillou, F. Sage, F. Michaud, W. Agudelo, P. Charvis, D. Graindorge, M.-A. Gutscher, and G. Spence (2004), Are rupture zone limits of great subduction earthquakes controlled by upper plate structures? Evidence from multichannel seismic reflection data acquired across the northern Ecuador-southwest Colombia margin, J. Geophys. Res., 109, B11103, doi:10.1029/2004JB003060.

Cummins, P. R., and Y. Kaneda (2000), Possible splay fault slip during the 1946 Nankai earthquake, Geophys. Res. Lett., 27, 2725-2728.

Delescluse, M., and N. Chamot-Rooke (2007), Instantaneous deformation and kinematics of the India-Australia Plate, Geophys. J. Int., 168(2), 818-842, doi:10.1111/j.1365246X.2006.03181.x.

DeMets, C., D. F. Gordon, D. F. Argus, and S. Stein (1994), Effect of recent revisions of the geomagnetic reversal time scale on estimates of current plate motions, Geophys. Res. Lett., 21, 2191-2194, doi:10.1029/94GL02118.

Deplus, C., M. Diament, H. Hébert, G. Bertrand, S. Dominguez, J. Dubois, J. Malod, B. Pontoise, and J.-J. Sibilla (1998), Direct evidence of active deformation in the eastern Indian oceanic plate, Geology, 26, 131-134, doi:10.1130/00917613(1998)026<0131:DEOADI > 2.3.CO;2.

Dewey, J. W., G. Choy, B. Presgrave, S. Sipkin, A. C. Tarr, H. Benz, P. Earle, and D. Wald (2007), Seismicity associated 
with the Sumatra-Andaman Islands earthquake of 26 December 2004, Bull. Seismol. Soc. Am., 97(1A), S25-S42, doi:10.1785/0120050626.

Engdahl, E. R, A. Villasenor, H. R. DeShon, and C. H. Thurber (2007), Teleseismic relocation and assessment of seismicity (1918-2005) in the region of the $2004 M_{w} 9.0$ SumatraAndaman and $2005 M_{w} 8.6$ Nias Island great earthquakes, Bull. Seismol. Soc. Am., 97(1A), S43-S61, doi:10.1785/ 0120050614

Fauzi, R. McCaffrey, D. Wark, Sunaryo, and P. Y. Prih Haryadi (1996), Lateral variation in slab orientation beneath Toba caldera, northern Sumatra, Geophys. Res. Lett., 23, 443-446, doi:10.1029/96GL00381.

Fitch, T. J. (1972), Plate convergence, transcurrent fault and internal deformation adjacent to Southeast Asia and the Western Pacific, J. Geophys. Res., 77(23), 4432-4460, doi:10.1029/JB077i023p04432.

Gaedicke, C., and S. Neben (2006), Report of the project: Cruise SO189 Leg1 SUMATRA-The Hydrocarbon System of the Sumatra Forearc, Bundesanst. für Geowiss. und Rohstoffe, Hannover, Germany. (Available at http://www.bgr.bund.de/ cln_101/nn_325028/EN/Themen/MeerPolar/Meeresforschung/ Projekte und Beitraege/Sumatra/so189 leg1 en.html)

Gahalaut, V. K., and K. Gahalaut (2007), Burma plate motion, J. Geophys. Res., 112, B10402, doi:10.1029/2007JB004928.

Gahalaut, V. K., B. Nagarajan, J. K. Catherine, and S. Kumar (2006), Constraints on 2004 Sumatra-Andaman earthquake rupture from GPS measurements in Andaman-Nicobar Islands, Earth Planet. Sci. Lett., 242(3-4), 365-374, doi:10.1016/j.epsl.2005.11.051.

Graindorge, D., et al. (2008), Impact of the lower plate on upper plate deformation at the NW Sumatran convergent margin from seafloor morphology, Earth Planet. Sci. Lett., 275, 201-210, doi:10.1016/j.epsl.2008.04.053.

Gudmundsson, O., and M. Sambridge (1998), A regionalized upper mantle (RUM) seismic model, J. Geophys. Res., 103, 7121-7136, doi:10.1029/97JB02488.

Henstock, T. J., L. McNeill, and D. R. Tappin (2006), Seafloor morphology of the Sumatran subduction zone: Surface rupture during mega thrust earthquakes?, Geology, 34, 485488, doi:10.1130/22426.1.

Hirata, K., et al. (2008), The fifth model for the huge tsunami generation off northwest Sumatra during the 2004 SumatraAndaman earthquake, Eos Trans. AGU, 89(53), Fall Meet. Suppl., Abstract G43B-02.

Hsu, Y.-J., M. Simons, J.-P. Avouac, J. Galetzka, K. Sieh, M. Chlieh, D. Natawidjaja, L. Prawirodirdjo, and Y. Bock (2006), Frictional afterslip following the 2005 Nias-Simeulue earthquake, Sumatra, Science, 312, 1921-1926, doi:10.1126/science.1126960.

Ishii, M., P. M. Shearer, H. Houston, and J. E. Vidale (2005), Extent, duration and speed of the 2004 Sumatra-Andaman earthquake imaged by the Hi-Net array, Nature, 435(7044), 933-936.

Kennett, B. L. N., and P. R. Cummins (2005), The relationship of the seismic source and subduction zone structure for the 2004 December 26 Sumatra-Andaman earthquake, Earth Planet. Sci. Lett., 239(1-2), 1-8, doi:10.1016/j.eps1.2005.08.015.

Kodaira, S., N. Takahashi, A. Nakanishi, S. Miura, and Y. Kaneda (2000), Subducted Seamount Imaged in the Rupture Zone of the 1946 Nankaido Earthquake, Science, 289, 104-106, doi:10.1126/science.289.5476.104.

Lahr, J. C. (1980), HYPOELLIPSE: A computer program for determining local earthquake hypocentral parameters, magnitude, and first motion pattern, U.S. Geol. Surv. Open File Rep., 80-59.
Lay, T., et al. (2005), The great Sumatra-Andaman earthquake of 26 December 2004, Science, 308(5725), 1127-1133, doi:10.1126/science. 1112250 .

Lienert, B., R. R. Berg, and L. N. Frazer (1988), HYPOCENTER: An earthquake location method using centered, scales, and adaptively least square, Bull. Seismol. Soc. Am., 76, $771-783$

McCaffrey, R. (1992), Oblique plate convergence, slip vectors, and forearc deformation, J. Geophys. Res., 97, 8905-8915, doi:10.1029/92JB00483.

McCaffrey, R. (2002), Crustal block rotations and plate coupling, in Plate Boundary Zones, Geodyn. Ser., vol. 30, pp. 101-122, edited by S. Stein and J. Freymueller, AGU, Washington, D. C.

Michel, G., et al. (2001), Crustal motion and block behavior in SE-Asia from GPS measurements, Earth Planet. Sci. Lett. 187, 239-244.

Moore, G. F., N. L. Bangs, A. Taira, S. Kuramoto, E. Pangborn, and H. J. Tobin (2007), Three-dimensional splay fault geometry and implications for tsunami generation, Science, 318, 1128 1131, doi:10.1126/science.1147195.

Moran, K., J. A. Austin, and D. R. Tappin (2005), Survey presents broad approach to tsunami studies, Eos Trans. $A G U, 86,430-432$, doi:10.1029/2005EO440005.

Mosher, D. C., J. A. Austin Jr., D. Fisher, and S. P. S. Gulick (2008), Deformation of the northern Sumatra accretionary prism from high-resolution seismic reflection profiles and ROV observations, Mar. Geol., 252, 89-99, doi:10.1016/ j.margeo.2008.03.014.

Nakanishi, A., S. Kodaira, J.-O. Park, and Y. Kaneda (2002), Deformable backstop as seaward end of coseismic slip in the Nankai Trough seismogenic zone, Earth Planet. Sci. Lett., 203, 255-263, doi:10.1016/S0012-821X(02)00866-X.

Newcomb, K. R., and W. R. McCann (1987), Seismic history and seismotectonics of the Sunda arc, J. Geophys. Res., 92, 421-439, doi:10.1029/JB092iB01p00421.

Nuannin, P., O. Kulhanek, and L. Persson (2005), Spatial and temporal $b$ value anomalies preceding the devastating off coast of NW Sumatra earthquake of December 26, 2004, Geophys. Res. Lett., 32, L11307, doi:10.1029/ 2005 GL022679.

Obana, K., S. Kodaira, K. Mochizuki, and M. Shinohara (2001), Nankai earthquake dislocation area, Geophys. Res. Lett., 28, 2333-2336, doi:10.1029/2000GL012794.

Park, J.-O., T. Tsuru, S. Kodaira, P. R. Cummins, and Y. Kaneda (2002), Splay fault branching along the Nankai subduction zone, Science, 297, 1157-1160, doi:10.1126/science.1074111.

Paul, J., et al. (2001), The motion and active deformation of India, Geophys. Res. Lett., 28(4), 647-650, doi:10.1029/ 2000GL011832.

Pietrzak, J., A. Socquet, D. Ham, W. Simons, C. Vigny, R. J. Labeur, E. Schrama, J. Battjes, G. Stelling, and D. Vatvani (2007), Defining the source region of the Indian Ocean Tsunami from GPS, altimeters, tide gauges and tsunami models, Earth Planet. Sci. Lett., 261, 49-64, doi:10.1016/ j.eps1.2007.06.002.

Plafker, G. (1972), Alaskan earthquake of 1964 and Chilean earthquake of 1960: Implications for arc tectonics, J. Geophys. Res., 77, 901-923, doi:10.1029/JB077i005p00901.

Pollitz, F. F., P. Banerjee, R. Burgmann, M. Hashimoto, and N. Choosakul (2006), Stress changes along the Sunda trench following the 26 December 2004 Sumatra-Andaman and 28 March 2005 Nias earthquakes, Geophys. Res. Lett., 33, L06309, doi:10.1029/2005GL024558.

Pubellier, M., C. Rangin, X. Le Pichon, F. Ego, C. Nielsen, A. Rabaute, H. T. Ngoc Nguyen, P. Pagot, and D. Tsang 
Hin Sun (2005), DOTSEA, Deep Offshore Tectonics of South East Asia, Mem. Soc. Geol., 176.

Sandwell, D. T., and W. H. F. Smith (1994), New global marine gravity map/grid based on stacked ERS1, Geosat and Topex altimetry, Eos Trans. $A G U, 75(16), 321$, Spring Meet.Suppl.,321.

Sibuet, J.-C., et al. (2007), 26th December 2004 great SumatraAndaman earthquake: Co-seismic and post-seismic motions in northern Sumatra, Earth Planet. Sci. Lett., 263(1-2), 88103.

Sieh, K., and D. H. Natawidjaja (2000), Neotectonics of the Sumatran Fault, Indonesia, J. Geophys. Res., 105, 28,29528,326, doi:10.1029/2000JB900120.

Soh, W., et al. (2005), Sea bottom shattered by the SumatraAndaman earthquake of 26 December 2004, Eos Trans. $A G U, 86(52)$, Fall Meet. Suppl., Abstract U11B-0842.

Stein, S., and E. A. Okal (2005), Speed and size of the Sumatra earthquake, Nature, 434(7033), 581-582, doi:10.1038/ 434581a.

Subarya, C., M. Chlieh, L. Prawirodirdjo, J.-P. Avouac, Y. Bock, K. Sieh, A. J. Meltzner, D. H. Natawidjaja, and R. McCaffrey (2006), Plate-boundary deformation associated with the great Sumatra-Andaman earthquake, Nature, 440(7080), 46-51, doi:10.1038/nature04522.

Sultan, N., A. Cattaneo, J.-C. Sibuet, J.-L. Schneider, and the Sumatra Aftershocks Team (2009), Deep sea in situ excess pore pressure and sediment deformation off NW Sumatra and its relation with the December 26, 2004 great SumatraAndaman earthquake, Int. J. Earth Sci., doi:10.1007/s00531008-0334-z, in press.

Thurber, C. H, and D. Eberhart-Phillips (1999), Local earthquake tomography with flexible gridding, Comput. Geosci., 25, 809-818, doi:10.1016/S0098-3004(99)00007-2.

Tsumura, K. (1967), Determination of earthquake magnitude from duration of oscillation, J. Seismol. Soc. Jpn., 2(20), $30-40$.

Vigny, C., et al. (2005), Insight into the 2004 SumatraAndaman earthquake from GPS measurements in southeast Asia, Nature, 436(7048), 201-206, doi:10.1038/nature03937.

Wang, K., and Y. Hu (2006), Accretionary prisms in subduction earthquake cycles: The theory of dynamic Coulomb wedge, J. Geophys. Res., 111, B06410, doi:10.1029/ 2005 JB004094.

Watts, A. B., and E. B. Burov (2003), Lithospheric strength and its relationship to the elastic and seismogenic layer thickness, Earth Planet. Sci. Lett., 213, 113-131, doi:10.1016/ S0012-821X(03)00289-9.

Wessel, P., and W. M. F. Smith (1991), Free software helps map and display data, Eos Trans. $A G U, 72,441-446$, doi:10.1029/90EO00319.

Zen, M. T. Jr. (1993), Déformation de l'avant-arc en réponse à une subduction à convergence oblique, Ph.D. thesis, 317 pp. Univ. Pierre et Marie Curie, Paris. 